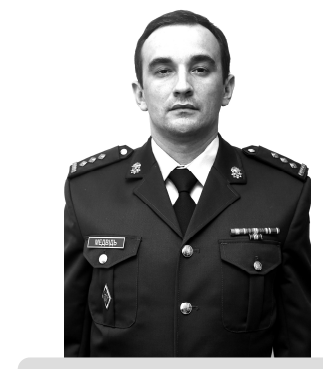

M. Medvid

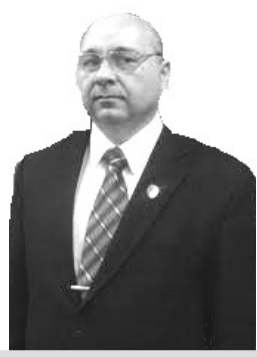

O. Babenko

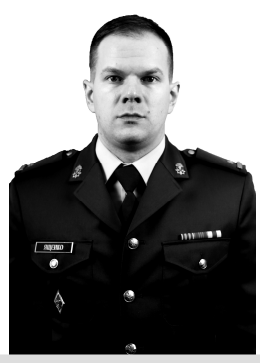

I. Yashchenko

\title{
THE ANALYSIS OF THE RESULTS OF THE MASSIVE SATURATION OF KIROVOGHRAD AREA WITH LANDMINES BY THE GERMAN INVADERS AS THEY RETREATED IN JANUARY 1944
}

The objective of the study is to analize the results of the massive saturation of Kirovoghrad area with landmines by the German invaders as they retreated in January 1944. The methodology of the study is based on the principles of historicism, systemic approach, proper academic assessment, verification, author objectivity and moderate narrative constructivism as well as the use of the general scientific methods such as analysis, synthesis and generalization. The scientific novelty is that first in history, to analyze the results of the massive saturation of Kirovoghrad area with landmines by the German invaders as they retreated in January 1944 based on previously unknown archival documents. Conclusions. It is about the scope and type of the massive saturation of the city with landmines by the Hitler troops as they retreated. Also it is told about the demining activities of residential buildings, industrial and infrastructural objects that were conducted by the combat engineers of the 27th Engineer Brigade (the Red Army) and there were described the modalities for the mining that were used for the regional centre planned destruction. It is given, according to the deminers, the brief analysis of the causes of not detonation of explosive devices and explosive ordnance. It is addressed the types of explosive devices, explosive ordnance and landmines that have been hidden into urban infrastructure.

Keywords: World War II, saturation of Kirovoghrad area with landmines, means of mining, military operation, demining activities of the combat engineers.

Problem statement. In the history of humankind, the World War II is remembered as the largest international armed conflict with the most devastating consequences compared to all other previous wars, including the World War I. During the World War II, in addition to the means of direct confrontation between the military factions of the parties to the conflict, the activities were aimed at weakening the enemy economic potential by destroying the industrial infrastructure were carried out on a scale destruction of industrial infrastructure, housing and the destruction of the civilian working population, which bore the brunt of the sustenance of an army and the livelihood of the State and its society. Along with the targetaimed weapons such as the most types of small arms, artillery and aircraft weapons, there is a variety of weapons with an indiscriminate effect, which include, among others, different mines and explosive devices. The indiscriminate effect of such weapons threatens not only combatants but (C) M. Medvid, O. Babenko, I. Yashchenko, 2021 also civilians (or their well-being) and their social survival with death or injury. Despite this, mines and various explosive devices continue to be used to destroy both military and non-military targets.

The analysis of sources and recent researches. The massive saturation of one of the regional centers such as Kirovoghrad area with landmines by the Nazi German troops during the hostilities in January 1944 is the example of the large-scale mine laying in a city with use of various engineering equipment in the history of Ukraine.

Despite numerous scientific studies and publications on the Kirovoghrad region liberation of the Nazi occupation, the issue of the city demining by the Red Army has not been adequately covered yet, although the adequate archive records are available for over 75 years $[1 ; 2]$.

First, the report of the 27th Separate Engineer Special Task Brigade command of the 2nd Ukrainian Front contains a detailed description of 
the enemy troops methods of the city preparation for demolition by the explosive, as well as the actions of the said brigade to rescue Kirovoghrad from total destruction. However, these archive records for a long time had varying degrees of restricted access. In the Ukrainian Second Liberation Competitions, the technical information and schemes that contained in the archive records had to be protected from use by "anti-Soviet elements" [3].

The publication's purpose. The purpose of this article is to familiarize the scientific community and the general public who keen of military history, with one of the pages of the World War II dramatic events. There are described, in particular, the preparation of Kirovograd area by the German troops for destruction, the city salvation by the Red Army, and the overview of landmines that have also been widely used by the sides of the confrontation throughout the Second Liberation Competition.

Statement of the basic material. The units of the 27th Special Engineering Special Brigade, under Colonel Vasilyev command, entered Kirovoghrad city together with the front units of the 2 Ukrainian Front. The Sappers started the city's engineering exploration. And, on January 8, 1944 when the city liberation occurred the Brigade has started to demine the city.

Because of reconnaissance, as well as while demining process it has become obvious that the city of Kirovograd was prepared in advance for demolition. The large-scale mine laying was conducted in the city. It was discovered, that all industrial objects, airfields, railroad infrastructure objects, cultural establishments, administrative buildings and even apartment building in the downtown and in the suburbs were totally saturated city with landmines.

The key infrastructure objects, factories and plants were totally saturated city with explosive. Among them, there were such objects as airfield, the Chervona Zirka plant, Balashiv Railroad Bridge, power plant, CRES dam, auto-repair shops and railway station. The Hitler troops also saturated with landmines the crossroads and the households. The Crimean street residential quarter at the Kushchivca village was totally covered with landmines. It were founded a lot of surprise mines installed in different administrative and living areas around the city.

Accordingly, the units of the 27th separate engineering brigade took urgent measures for the continuous demining of the entire territory of
Kirovograd, and completed that on January 31, 1944. A total of 160.6 tons of explosives of various power and volumes were found and neutralized by sappers between January 8 and 31 [3, p. 8].

The city saturation with landmines was conducted by Hitler troops according to the predeveloped plan. Mines, toluene, donorite charges, air bombs of various calibers, and artillery shells were used as weapons of destruction of the city. In addition, other types of explosive devices were used, and in some cases even grenades.

Most of the landmines that were installed in different places, were designed for electric blasting. Each facility had a complex explosive network that was connected to switchboard switches or to the city's general power network. The command of the 27th Brigade believed that the Germans hoped to blow up all the facilities by getting power to the city from the power plant.

A small number of objects were equipped with another way to initiate the explosion. Most often, these were the so-called "surprises" tripwire or pressure activated, or various ways of short circuit in the switchboard, which was carried out from a separate mechanism.

At the same time, the explosive ordnance system and the construction of the explosive network made it possible to carry out an explosion not only from the Kirovograd power network, but also from any other one, even from a mobile power plant that could be located outside the city. A special electrical connection was created for this purpose. In this case, the detonation of the city could be carried out, even if the city was already occupied by Red Army troops.

Before leaving the city, Wehrmacht units managed to blow up some enterprises, which led to their complete or partial destruction. However, the Germans failed to implement fully their plan to destroy the city. The reason for this, apparently, was the rapid offensive of the Red Army and the threat of German troops surrounding (which led to the retreat of the latter), the pace of the city liberation by Soviet troops. However, not only this led to the salvation of the city. Analyzing the wellknown facts about the Kirovograd offensive operation, we can conclude that the Germans had enough time to complete works on mining the city, and therefore - the opportunity to launch infernal mechanisms. The research of the mining system revealed that despite the large-scale works on the explosive devices and electrical equipment installation, a number of miscalculations were 
revealed due to the negligence of the performers and the poor quality of the explosive network.

For example, electric detonators in the electric blasting method had to be calibrated within the electrical resistance. In fact, this was not done, as there were differences in characteristics $[3$, p. 8$]$. The difference exceeded $40 \mathrm{ohms}$, which led to a complete failure of the network and provided, in extreme cases, only its incomplete operation. For example, at some sites, which were blown up by German sappers on the ground from third-party power sources, the system failed, so only part of the landmines exploded. It turned out that the wires were carelessly soldered, which caused additional electrical resistance.

Some of the detected landmines were designed for slow action, such as a high-powered landmine planted in the building № 8 of the airfield. But due to haste in retreat or other reasons unknown to us, the appropriate detonators were not installed on landmines.

Now the late Kirovograd local historian Vadym Smotrenko told the story of a semi-legendary janitor who accidentally saved the central part of the city from an explosion, damaging in the attic of one of the houses or wires to the detonator or Bickford cord held to boxes of dynamite. One way or another, Kirovograd was saved from the landmines.

At some industrial enterprises in Kirovograd, Soviet sappers found large-caliber aircraft bombs planted on which the Germans managed to install detonators with time mechanisms. These bombs were removed and destroyed or neutralized on the spot.

It is possible that, according to the German command intent, these bombs were to detonate during the Luftwaffe squadrons intensified air bombardment of the city, liberated by Red Army units. On January 8 and 9, 1944, German bombers did carry out brutal attacks on Kirovograd. However, Red Army sappers removed most of the detonators at all major city sites on January 8 , even before the bombing began, and saved much of the city from being blown up.

The report on demining formulates a conclusion about the reasons for the above: the low quality of German minesweepers, as well as the imperfection of their combat training [3, p. 9].

A total of 2,124 explosive devices weighing 145 tons were defused in the city. Demining prevented the destruction of more than 50 important objects. Thus, landmines and aerial bombs weighing 5 tons were removed in the shops of the Chervona Zirka plant. Car workshops on
Teatralna Street were mined with 8 tons of ammunition. 3 tons of explosives and 180 anti-tank mines were neutralized at the rope factory. IEDs made of explosive and 80-ton aircraft bombs were found only at the airfield. The KRES dam on the Ingul River was loaded with 14 landmines and air bombs weighing more than 5 tons [3, p. 11].

Among the surprise traps, the sappers noted a high-power explosive device located in the premises of a tobacco factory. A 900-kilogram IED with a push-button electric switch was installed there. The electric switch was disguised under the steps on the steps. If a person stepped on the steps, not only the factory but also the buildings around would be destroyed by an explosion.

A strategically important railway bridge across the Ingul River, a knitwear factory, a theater, a concentration camp, a mill on Teatralna Street, a railway depot, railway depots, a water pump and other important infrastructure were also prepared for the explosion. To detonate them, the Nazis used 624 engineering explosives and charges, 50 bombs converted into landmines, 832 pieces of SD-1 and SD-2 bombs, 18 artillery shells and various grenades. The number of various explosive devices-surprises reached 23.

A significant amount of mining equipment was found in warehouses. Thus, the Red Army received as trophies: 819 anti-tank mines found in the bread factory near the railway, and 219 similar mines stored in the rope factory, 9276 anti-personnel mines in the bread factory, 62 mortar mines in boxes at the rope factory, 10800 detonators, 9000 capsule detonators and 600 electric detonators stored in the bakery.

According to the available archive records, we can classify the explosive devices involved in the mining scheme of Kirovograd by the method of detonation. Thus, among those discovered by the Red Army sappers were the following explosive device, such as electrically initiated (with wires connected to the general power network, to the switchboard, to the electric booth, to the switch, to the electric pole, as well as various autonomous power source, like diesel power station and internal combustion engine), «surprises» tripwire or pressure activated, or with the fire method of detonation (i.e. with the Bickford cord) and part of the charges were to detonate with the explosive time-delayed devices. The anti-tank mines and the magnetic mines were also found [3, p. 9].

Among the air bombs, the use of German bombs of $1000 \mathrm{~kg}, 500 \mathrm{~kg}, 250 \mathrm{~kg}, 100 \mathrm{~kg}, 50 \mathrm{~kg}$, as well as SD-1 and SD-2 bombs were noted. In addition, among the mines were anti-tank mines TM-42, 
TM-35 and TM-25, as well as magnetic mines. Other types of ammunition include artillery shells, mortar mines and infantry grenades [3, pp. 9-10].

Among the explosives used by German sappers to create IED to mine Kirovograd were tol and donarite. Tol in the 1940s was also called TNT or trinitrotoluene. It was obtained by a chemical reaction between toluene and nitric acid with sulfuric acid. Toluene is a liquid obtained from the distillation of coal or oil, as well as from the production of coke.

Tol at that time was of three types. They are of crystal powder of light yellow color, pressed tol in the form of yellow checkers and melted tol in the form of pieces and checkers of yellow-brown color.

In the bomber masterminding of the 1930s, pressed and fused toluene was most often used in the form of a sticks of dynamite. Stickers were made in the form of a parallelepiped of different sizes (large $-5 \times 5 \times 10 \mathrm{~cm}$ and weighing $400 \mathrm{~g}$, or small $-2.5 \times 5 \times 10 \mathrm{~cm}$ and weighing $200 \mathrm{~g}$ ). The extruded sticks were waxed, wrapped in paper wrappers, and then waxed again. Each stick had a slot-hole with a diameter of $7 \mathrm{~mm}$ and a depth of $30 \mathrm{~mm}$ for the detonator capsule. The toll used in Nazi Germany had the code "S-02" or "Fp-02". The standard charge of toluene weighed $3 \mathrm{~kg}$ and was packed in a wooden box measuring $195 \times 164 \times 76 \mathrm{~mm}$. Tol was also used to arm artillery shells, air bombs, hand grenades, naval and anti-tank mines, torpedoes and more. The most valuable qualities of TNT were considered the power and ability to store for 10-30 years without loss of combat qualities [4, pp. 8-11].

Donarite was a mixture of explosives, $80 \%$ of which was ammonium nitrate, $12 \%$ - TNT, $4 \%-$ wheat flour, 3,8 \% - nitroglycerin, $0,25 \%$ colloidal cotton. Donarite was an explosive created based on ammonium nitrate and nitroglycerin in the early twentieth century as a cheap substitute for dynamite. Donarit is a light brown powder of a slightly dirty hue. He replaced dynamite with great success in stonemasonry and salt mines [5, p. 572].

The Tellermine 35 anti-tank mine (T.Mi.35) was in fact a further development of T.Mi.29. A prototype of these explosive devices was developed at the end of the First World War as means to combat British tanks. During the 1920s and 1930s, the mine was gradually improved, and, as a result, T.Mi.35 and T.Mi.35St were created. And 2.2 million mines of such types were produced only in $1942-43$. The mine was a metal body with a diameter of $32 \mathrm{~cm}$ and a total height of $10.5 \mathrm{~cm}$. The weight of the explosive reached $5 \mathrm{~kg}$, and the total weight of the mine was $10 \mathrm{~kg}$. A special TMiZ-35 detonator with two fuses was screwed into the central part of the pressure cover. One of them had the form of a screw head in the upper satin of the detonator and had two positions - "safe" and "dangerous". The second fuse was a check placed in the side tide of the blasting cap. It was pulled out with a rope. The mine exploded under the weight of 90-190 kg, which pressed on the pressure plate. On the side and at the bottom of the case, the mine had capsule sockets for tripwireactivated blasting cap to set the mine to selfdetonation mode when trying to remove it.

During the war, the T.Mi.35 mine was upgraded by installing a TMiZ-42 fuse. Unlike its predecessor, this blasting cap was installed in the ignition cup freely, without screwing, and was not connected to the mine pressure plate. Accordingly, the central hole in the mine plate was closed with a threaded plug, which transmitted pressure to the head of the detonator strike. A rubber washer was laid under the cork to seal the ignition cup. The mine exploded under the weight of $240-300 \mathrm{~kg}$. Transportation of a mine with a TMiZ-42 detonator installed was strictly prohibited. Blasting caps were transported separately from mines in special containers and were installed directly during mining.

The Tellermine 42 anti-tank mine (T.Mi.42) had a stamped metal body. In the center of the body there was an ignition cup, into which the main blasting cap TMiZ-42 was inserted. On the side opposite the handle of the mine body, and in the bottom there were sockets for tripwire-activated blasting caps, which were used to set the mine to the mode of selfdetonation when trying to remove it. The top of the mine was covered by a pressure plate, which was screwed into the ignition cup and was designed to transfer pressure to the head of the detonator. Sealing of the ignition cup was achieved by a rubber washer, which was put on the thread of the cap of the pressure cap. The mine exploded by weighing about $320 \mathrm{~kg}$. The diameter of the mine was $31 \mathrm{~cm}$, and the height was $8.5 \mathrm{~cm}$. The weight of the charge was about $5 \mathrm{~kg}$. [6, pp. 3-9].

The German air bombs used in the mining were divided into high explosive - so-called SprengbombeCylindrisch (SC) with caliber of 50, $100,250,500,1000 \mathrm{~kg}$ and fragmentation SD-1 and SD-2 bombs. The German high-explosive air bomb SC-50 had a cast thick-walled case with a shank with four stabilizers that was screwed to the bomb body with screws. The electric detonator was 
on the side of a bomb. At a weight of $55.5 \mathrm{~kg}$, the mass of the explosive reached $24.4 \mathrm{~kg}$.

High-explosive air bombs SC-100, SC-250, SC-500, SC-1000 had a forged thin-walled cylindrical case, with a welded conical nose part and the tail part with stabilizers was screwed in various ways. The most common in use was the SC-250 bomb weighing $250 \mathrm{~kg}$ and armed with $130 \mathrm{~kg}$ of explosives. Accordingly, SC-1000 bomb weighed $1020-1090 \mathrm{~kg}$ and had $530-620 \mathrm{~kg}$ of explosive. The detonator of this type of bomb was also located on the side and could be both instantaneous electricaly activated and mechanical delay-action of up to two hours. The location of the place for the detonator allowed using it for other types of detonators, including for use as stationary IED for blasting.

The SD-1 air bomb was a remanufactured 50-mm mortar mine. An instantaneous mechanical bomb fuse replaced its standard blasting cap. Then the shank with gunpowder was removed from the mine, and in its place was mounted an aircraft tail with eight aluminum stabilizers. The weight of the bomb reached $760 \mathrm{~g}$, of which $110 \mathrm{~g}$ were explosives. SD-1 bombs could be used as submunitions for cluster munitions. Depending on the size of the container, it could accommodate from 50 to 392 SD-1 bombs.

The SD-2 anti-personnel fragmentation bomb was a submunition of cluster bombs designed to destroy enemy personnel. The bomb consisted of a case, an outer casing, a fuse and a connecting cable. The case of the bomb was a thick-walled cast iron cylinder containing explosives. A fuse hole was made on the side of the case. A short metal cable stretched from the fuse, to which a windmill with two blades or with two disks and half-barrels was attached. When SD-2 bomb fell out of the container, the windmill opened, the blades or semi-discs with disks shifted up the cable and, rotating, untwisted the cable that unscrewed the safety pin from the fuse, arming a bomb-mine. Depending on the type and setting of the fuse, the bomb detonated either in the air, or at the time of impact on the ground, or in some time after landing when trying to defuse the bomb or just move it. The weight of the SD-2 bomb reached $2 \mathrm{~kg}$. It was armed with $213 \mathrm{~g}$ of explosives. Depending on the type of container, the cluster bomb contained from 6 to 360 SD-2 bombs. The dual purpose of the bomb allowed it to be used to mine territory in order to kill people, not only the military [7, p. 572].

\section{Conclusions}

Considering the above, certain conclusions can be drawn. These data indicate that the Wehrmacht's engineering or sapper units had a significant arsenal of mining tools, and therefore extensive experience in a variety of mining operations, buildings and infrastructure. This gave them the opportunity, if necessary, to organize areas of continuous or local demolition, depending on the tasks. German engineers used various explosives to mine Kirovograd and the main one being trinitrotoluene. They also widely used high-explosive air bombs as IED, as there were plenty of them in Kirovograd at the city's hub airfield, as well as Kanatovo airfield near the city. In addition, there was a railway station in Kirovograd with a sufficient number of warehouses and storage facilities. German sappers also showed exceptional ingenuity in using standard anti-tank mines, artillery shells, mortar mines, etc. to mine the city. A significant number of "booby traps" were left in the city.

At the same time, the Wehrmacht specialists trying to oppose the rapid development of the Kirovograd Red Army offensive apparently did not have as much time to mine the city as their Soviet opponents thought, as evidenced by the careless installation of the power network to blow up the city.

It should also be noted the prompt reaction of Soviet engineering units, which began demining immediately after the expulsion of the Nazis from the city, without waiting for the destruction of the besieged German troops in the immediate vicinity of Kirovograd. As a result, on January 8, 1944, detonators were removed from the most powerful IED. Due to this, the charges were not detonated during the first strikes on the city by German bombers. Their attacks lasted from noon on January 8, 1944 until the morning of January 9, 1944. According to the command of the 27th special engineering brigade of the 2nd Ukrainian Front, the Luftwaffe squadrons bombed the city due to the lack of detonation of the mine-laying system and with the expectation of its detonation. However, in our opinion, currently this version remains only a guess. 


\section{References}

1. Levchenko Yu. I. realizaciyi okupacijnoyi polity`ky` $\mathrm{v}$ administraty`vno-tery`torial`ny`x ody`ny`cyax Ukrayiny` $1941-1944$ rr.: istoriografiya [Features of Realization of Occupation Politics are in Administrative-Territorial Units of Ukraine in 1941 - 1944: Historiography]. Storinky` istoriyi Pages of history. 38. 2014. 107-126. DOI: $10.20535 / 2307-5244.38 .2014 .90989$

[in Ukrainian].

2. Shevchenko B. L. Do istoriyi Kirovograds 'koyi nastupal 'noyi operaciyi 2-go ukrayins kogo frontu u sichni 1944 roku [To the History of Kirovohrad Offensive Operation of 2nd Ukrainian Front in January 1944]. Vijs 'kovonaukovy j visny`k - Military-scientific bulletin, 29. $2018 . \quad 79-89 . \quad$ DOI: $10.33577 / 2313-$ 5603.29.2018.79-89 [in Ukrainian].

3. Dopovid' nachal'ny'ka shtaba 27-yi okremoyi inzhenernoyi bry'gady' special'nogo pry`znachennya pro rezul 'taty' rozminuvannya $\mathrm{m}$. Kirovograda z 8 do 18 sichnya 1944 r. [The 27th separate special engineering brigade Chief of Staff report on the results of demining in Kirovograd in the period of January 8 to 18,1944 .]. Records fund P-429, description 4, case 85. Kirovoghrad region State Archive, Kropivnytzkyi city [in Ukrainian].

4. Volkov I. V., Radevich P. G. Podryivnaya tehnika $i$ minirovanie [Engineer blasting equipment and mine laying] (3rd ed.). 1944. Moskva : Voennoe izdatelstvo narodnogo komissariata oboronyi [in Russian].

5. Suharevskiy P. Vzryivchatyie veschestva $i$ vzryivnyie rabotyi [Explosive and blasting]. Vol. 1. 1923. Moskva : Gosudarstvennoe tehnicheskoe izdatelstvo [in Russian].

6. Minno-podryivnyie sredstva protivnika [Enemy mine-subversive weapons] (1944). Moskva : Voennoe izdatelstvo narodnogo komissariata oboronyi [in Russian].

7. Shirokorad A. B. Istoriya aviatsionnogo vooruzheniya [The history of Air Weapons]. Brief notes. In Taras A. (ed.) Minsk : Harvest [in Russian]. 1999.

The article was received by the editors 04.02.2021.

\title{
УДК 94(477.8):355.443 “1944”
}

\author{
М. М. Медвидь, О. А. Бабенко, И. В. Ященко
}

\section{АНАЛИЗ РЕЗУЛЬТАТОВ МИНИРОВАНИЯ КИРОВОГРАДА НЕМЕЦКИМИ ОККУПАНТАМИ ПРИ ОТСТУПЛЕНИИ В ЯНВАРЕ 1944 ГОДА}

Проанализированы результаты минирования Кировограда немечкими оккупантами при отступлении в январе 1944 2. Методология исследования опирается на принципь историзма, системности, научности, верификаџии, авторской объективности, умеренного нарративного конструктивизма, а также на использование общенаучных (анализ, синтез, обобщение) методов. Впервые в истории на основе не известных ранее архивных документов проанализированы результаты минирования Кировограда немеикими оккупантами при отступлении в январе 1944 г., которые свидетельствуют о масштабах и характере минирования города гитлеровцами накануне отступления, мероприятиях саперов 27-й отдельной инженерной бригады Красной Армии по разминированию жилых зданий, промышленных и инфраструктурных объектов, а также средствах минирования, применяемых для запланированного разрушения областного иентра. Дан короткий анализ причин, которые, по мнению снайперов, не привели к действию смертоносной сети взрывных устройств и боеприпасов, предназначенных для подрыва. Рассмотрены виды взрывчатки, боеприпасов и фугасов, которые были заложены в городской инфраструктуре.

Ключевые слова: Вторая мировая война, минирование Кировограда, способы минирования, операции войск, мероприятия саперов. 
УДК 94(477.8):355.443 “1944”

М. М. Медвідь, О. О. Бабенко, І. В. Ященко

\section{АНАЛІЗ РЕЗУЛЬТАТІВ МІНУВАННЯ КІРОВОГРАДА НІМЕЦЬКИМИ ОКУПАНТАМИ ПІД ЧАС ВІДСТУПУ У СІЧНІ 1944 РОКУ}

Проаналізовано результати мінування Кіровограда німецькими окупантами під час відступу у січні 1944 р. Методологія дослідження трунтується на принципах історизму, системності, науковості, верифікаиії, авторської об'єктивності, поміркованого наративного конструктивізму, а також на використанні загальнонаукових (аналіз, синтез, узагальнення) методів. Уперше в історії на основі не відомих раніше архівних документів проаналізовано результати мінування Кіровограда німецькими окупантами під час відступу у січні 1944 р., які свідчать про масштаби та характер мінування міста гітлерівиями напередодні відступу, заходи саперів 27-ї окремої інженерної бригади спеціального призначення 2-го Українського фронту Червоної Армії щьоо розмінування житлових будівель, промислових та інфраструктурних об'єктів, а також засоби мінування, застосовані для запланованого руйнування обласного центру. Система установки фугасів та устрій вибухової мережі давали можливість здійснити вибух не тільки від кіровоградської електромережі, але й від будь-якої іншої, навіть від пересувної електроустановки, що могла знаходитися поза межами міста. Для иього було створено спеціальний відвід. Підрив об’єктів міста міг бути реалізованим, навіть коли б місто вже було зайняте військами Червоної Армії.

Подано короткий аналіз причин, які, на думку саперів, не спричинили приведення у дію смертоносної мережі вибухових пристроїв та боєприпасів, призначених для підриву. Відзначено оперативну реакиію радянських інженерних підрозділів, щцо розпочали розмінування одразу після витіснення гітлерівців з міста. Було знято детонатори з найбільш потужних фугасів. Завдяки цьому заряди не здетонували під час перших же ударів по місту німецьких бомбардувальників. Ескадрильї Люфтваффе бомбардували місто внаслідок відсутності підриву системи мінування із розрахунком на ї̈ детоначію.

Розглянуто види вибухівки, боєприпасів та фугасів, що були закладені у міську інфраструктуру.

Ключові слова: Друга світова війна, мінування Кіровограда, засоби мінування, операчї̈ військ, заходи саперів.

Medvid Mykhailo - Doctor of Economic Sciences, Professor, Deputy Head of Training and Methods Centre - Head of Methods Department of the National Academy ot the National Guard of Ukraine

https://orcid.org/0000-0002-4506-8020

Babenko Oleg - Head of State Archive department in Kirovoghrad region https://orcid.org/0000-0001-6590-0032

Yashchenko Illia - senior teacher, language training service, language department, National Academy of National Guard of Ukraine

https://orcid.org/0000-0002-6007-5237 